\title{
The Influence of Continuous Organic Manure Application on Chemical Properties and Organic Carbon of Cultivated Soils
}

\author{
A.S. Al-Malik \\ Soil Sciences Department, College of Food \& Agricultural Sciences, King Saud \\ University, P.O. Box 2460, Riyadh 11451, Kingdom of Saudi Arabia
}

\begin{abstract}
A study was conducted to determine the effects of short- and long-term application of organic manure on soil chemical properties including soil $\mathrm{pH}, \mathrm{EC}, \mathrm{CaCO}_{3}, \mathrm{SOC}$, and soil available $\mathrm{N}$ and $\mathrm{P}$ under arid conditions. The solid and liquid organic manure were applied to the soils cropped with the vegetable for either up to 2-years under vegetable plants or 15 -years to soils cropped with fruit trees. Soil samples were collected at sampling depths of 0 $15,15-30,30-45,45-60 \mathrm{~cm}$. Results showed that the soil organic carbon (SOC) content ranged between $0.6-12 \mathrm{~g} \mathrm{~kg}^{-1}$ and $1.7-31.5 \mathrm{~g} \mathrm{~kg}^{-1}$ after organic manure application for one year and $15-$ years in soil samples cropped with fruit trees, respectively. Moreover, SOC content ranged between 0.6 and $6.4 \mathrm{~g} \mathrm{~kg}-1$ and 0.9 and $8.6 \mathrm{~g} \mathrm{~kg}^{-1}$ after organic manure application for the one year and 2-years in soil samples cropped with vegetable, respectively. The highest soil available $\mathrm{N}\left(211 \mathrm{mg} \mathrm{kg}^{-1}\right)$ was found after long term application of organic manure (15-years) followed by that $\left(162 \mathrm{mg} \mathrm{kg}^{-1}\right)$ found after the 2-years organic manure application. The higher soil available $P\left(52-60.2 \mathrm{mg} \mathrm{kg}^{-1}\right)$ was also found with 15-years and 2-years application of organic manure. It could be concluded that the addition of organic manure to the soil of arid condition may be suitable for maintaining soil organic carbon and improving soil fertility by increasing $\mathrm{N}$ and $\mathrm{P}$ availability.
\end{abstract}

Key words: Organic manure, soil organic carbon, soil available nitrogen, soil available phosphorus.

\section{INTRODUCTION}

Among the soils used for agriculture in arid conditions are the calcareous sandy soils. In calcareous soil, the high content of $\mathrm{CaCO}_{3}$ and high soil $\mathrm{pH}$ could reduce the availability of nutrients to plants (Wassif et al., 1995). Amelioration of these soils is a must to improve their productivity. In this context, the use of soil conditioners like organic wastes could be practiced for this purpose. The use of organic manures with high organic matter, $\mathrm{N}$ and $\mathrm{P}$ contents may improve soil properties for agricultural use (Wassif et al., 1995; Morera et al., 2002; Bouajil and Sana, 2011; Diacono and Montemurro, 2010; Miller and Miller, 2000).

Soil quality is a complex characteristic and is determined by the physical, chemical and biological components of the soil (Manna et al., 2005; Johansson et al.,1999). Changes in soil physico-chemical and biological characteristics are considered good indicators of soil quality. The fact is that soil chemical and biological properties change when soil organic carbon content is increased due to organic amendments (Diacono and Montemurro, 2010; Bouajil and Sana, 2011). There is evidence that organic residues can improve soil fertility by increasing nutrient availability (Bouajil and Sana, 2011). In soils, impact of addition of organic amendments on SOC and nutrients availability was investigated by several authors (Richard et al., 1995; Hue 1991; Hou et al., 2012). Organic manure will maintain soil organic carbon as well as add $\mathrm{N}$ and other nutrients to the soils for agronomic crops (Triberti et al., 2008). Additionally, organic amendments may increase the solubility and availability of $P$ in soils (Hue, 1991; Iyamuremy et al., 1996a; 1996b; 1996c). 
Assessment of dynamics of soil organic carbon (SOC) and chemical soil properties under arid conditions after long term application of organic manure can help to draw the useful conclusion for their contribution. There is currently no available information about the effects of the long term application of organic manure on SOC and chemical soil properties in arid conditions in Saudi Arabia. Therefore, the objective of this study was to determine effects of the short and long term application of organic manure on soil chemical properties including soil $\mathrm{pH}, \mathrm{EC}, \mathrm{CaCO}_{3}, \mathrm{SOC}$, and soil available $\mathrm{N}$ and $\mathrm{P}$ under arid conditions.

\section{MATERIALS AND METHODS}

The study area is located in the northern part of Saudi Arabia at Al Juaf (lat 29' 49" N, long 39' 52" E). According to Soil Survey Staff (2006), the area was classified as Aridic-Hyperthermic zone. The solid organic manure was applied to the soils for either up to 2 years under vegetable crops or 15 years under fruit trees. Soil samples were collected at sampling depths of 0-15, 15-30, $30-45,45-60 \mathrm{~cm}$. The disturbed surface and subsurface soil samples for physico-chemical analyses as well as the total content of organic carbon were collected from soil profiles under fruit trees or vegetable plants. All soil samples were air-dried at room temperature $\left(20-22^{\circ} \mathrm{C}\right)$ and ground to pass through a 2$\mathrm{mm}$ sieve. The particle size distribution was determined by the pipette method (Gee and Bauder, 1994). Soil texture is ranging between sand and sandy clay loam. Soil chemical properties were measured according to standard methods (Sparks 1996). Soil pH was measured using a glass electrode in a suspension of saturation soil paste. Electrical conductivity (EC) was measured in the soil extracts of saturation soil paste. Calcium carbonate content was determined using a calcimeter. The soil organic matter was measured according to Nelson and Sommers (1996). Soil available inorganic $\mathrm{N}\left(\mathrm{NH}_{4}-\mathrm{N}\right.$ and $\left.\mathrm{NO}_{3}-\mathrm{N}\right)$ was determined according to Keeney and Nelson(1982). Also, ammonium bicarbonate extractable phosphorus was determined colorimetrically according to Soltanpour and Workman (1979).

\section{Statistical analysis}

The values of mean are calculated. The statistical analysis was performed by using Statistica for Windows Statistical Software (StatSoft, 1995).

\section{RESULTS AND DISCUSSION}

\section{Effects of organic manure on soil chemical properties}

Table 1 shows the average values of the measured soil chemical properties as affected by organic manure application. In addition, table 2 shows significance at the 0.05 and 0.01 probability levels. The $\mathrm{pH}$ values of soil samples ranged between 7.94 and 8.85 in soil samples of fruit trees and between 8.00 and 8.85 in samples of vegetables soils (Table 1). The high values of soil $\mathrm{pH}$ may be attributed to the high free $\mathrm{CaCO}_{3}$ content in soil.

The EC values ranged between 0.002 and $0.461 \mathrm{dSm}^{-1}$ in soil samples of fruit trees and between 0.098 and $0.379 \mathrm{dSm}^{-1}$ in soil samples of vegetable crops (Table 1). Generally, the EC values were lower at surface layers after short term of organic manure application than those after long-term of organic manure application. This suggests that the continuous application of organic manure, for long time, may be responsible for the increasing soil salinity. 
However, these increases in EC did not reach to the high levels that may be responsible for damaging plants. The results also indicated that the long-term application (15-years) of organic manure showed lower EC values than the short-term application (1-year) with increasing sampling depth of fruit soils. One possible reason is that the long term of organic manure application may lead to enhance root growth of fruits trees, resulting in depletion of nutrient and solutes from lower depths and subsequently decreasing soil salinity. The $\mathrm{CaCO}_{3}$ contents ranged between 3.8 and $8.40 \%$ in soil samples of fruit trees and between 3.2 and $9.2 \%$ in soil samples of vegetable soils (Table 1). It was observed that there are significant differences in $\mathrm{pH}, \mathrm{EC}$ and $\mathrm{CaCO}_{3}$ content values between 1-year and 15-years application under fruit trees and between 1-year and 2-years under vegetable crops of the surface layer (Table 2). This can be explained by the effects of organic manure on soil physico-chemical properties.

Table (1). Soil chemical properties of the soil profile under fruit trees and vegetable crops

\begin{tabular}{cccccccccccccc}
\hline \multirow{2}{*}{$\begin{array}{c}\text { Soil } \\
\text { depth }\end{array}$} & \multicolumn{4}{c}{ Under Fruit Trees } & \multicolumn{4}{c}{ Under Vegetables } \\
\cline { 2 - 14 } & \multicolumn{4}{c}{ 1-year Application } & \multicolumn{3}{c}{$\begin{array}{c}\text { 15-years } \\
\text { Application }\end{array}$} & \multicolumn{3}{c}{ 1-year Application } & \multicolumn{4}{c}{$\begin{array}{c}\text { 2-years } \\
\text { Application }\end{array}$} \\
\cline { 2 - 14 } & $\mathbf{p H}$ & $\mathrm{EC}_{\mathrm{e}}$ & $\mathrm{CaCO}_{3}$ & $\mathbf{p H}$ & $\mathrm{EC}_{\mathrm{e}}$ & $\mathrm{CaCO}_{3}$ & $\mathbf{p H}$ & $\mathrm{EC}_{\mathrm{e}}$ & $\mathrm{CaCO}_{3}$ & $\mathbf{p H}$ & $\mathrm{EC}_{\mathrm{e}}$ & $\mathbf{C a C O}_{3}$ \\
\hline $\mathbf{0 - 1 5}$ & 8.22 & 0.002 & 8.40 & 8.28 & 0.269 & 7.10 & 8.30 & 0.23 & 9.20 & 8.28 & 0.258 & 8.30 \\
$\mathbf{1 5 - 3 0}$ & 8.82 & 0.183 & 8.10 & 8.85 & 0.141 & 8.20 & 8.00 & 0.379 & 7.30 & 8.39 & 0.158 & 7.10 \\
$\mathbf{3 0 - 4 5}$ & 8.47 & 0.461 & 4.10 & 7.94 & 0.002 & 6.10 & 8.68 & 0.122 & 4.50 & 8.34 & 0.190 & 5.10 \\
$\mathbf{4 5 - 6 0}$ & 8.64 & 0.189 & 4.60 & 8.15 & 0.002 & 3.80 & 8.69 & 0.098 & 3.90 & 8.85 & 0.098 & 3.20 \\
\hline
\end{tabular}

Table (2). Summary statistics showing significance at 0.05 and 0.01 probability levels

\begin{tabular}{|c|c|c|c|c|c|c|}
\hline .Effects/property & pH & EC & $\mathrm{CaCO}_{3}$ & OC & Soil available $\mathbf{N}$ & Soil available $\mathbf{P}$ \\
\hline \multicolumn{7}{|c|}{ Under fruit trees } \\
\hline Depth (1-year Application ) & ** & ** & ** & ** & ** & ** \\
\hline Depth (15-years Application ) & ** & ** & ** & ** & ** & ** \\
\hline Year (0-15 cm depth) & * & * & ** & ** & ** & ** \\
\hline Year (15-30 cm depth) & NS & ** & NS & NS & ** & * \\
\hline Year (30-45 cm depth) & ** & ** & ** & ** & NS & NS \\
\hline Year (45-60 cm depth) & NS & ** & ** & NS & NS & NS \\
\hline \multicolumn{7}{|c|}{ Under vegetable crops } \\
\hline Depth (1-year Application ) & NS & $\star * *$ & ** & ** & ** & ** \\
\hline Depth (2-years Application) & $* *$ & ** & ** & ** & ** & ** \\
\hline Year (0-15 cm depth) & ** & ** & ** & ** & ** & ** \\
\hline Year (15-30 cm depth) & NS & ** & ** & ** & ** & NS \\
\hline Year (30-45 cm depth) & NS & ** & ** & NS & NS & NS \\
\hline Year (45-60 cm depth) & NS & NS & ** & ** & NS & NS \\
\hline
\end{tabular}

NS: not significant; * significant at $p<0.05 ;{ }^{* *}$ significant at $p<0.01$ 


\section{Effects of organic manure on OC content and distribution of soil profile}

Soil organic matter plays a major role in the improvement of soil physical, chemical and biological properties. It has been reported that organic matter of soils (especially of sandy soils) is a very valuable property, mainly due to its high capacity for water and nutrient-holding. Additionally, its decay in soils could provide recycled essential nutrients to plants. Figure 1 shows the average values for measuring SOC as affected by organic manure application. In addition, Table 2 shows significance at the 0.05 and 0.01 probability levels. The results showed that the SOC contents ranged between 0.6 and $12 \mathrm{~g} \mathrm{~kg}^{-1}$ after organic manure application for the 1-year and between 1.7 and $31.5 \mathrm{~g} \mathrm{~kg}^{-1}$ after manure application for 15-years in soil samples of fruit trees (Figure 1). Moreover, the SOC contents ranged between 0.6 and $6.4 \mathrm{~g} \mathrm{~kg}^{-1}$ and 0.9 and 8.6 $\mathrm{g} \mathrm{kg}^{-1}$ after organic manure application for 1-year and the 2-years in soil samples of vegetable crops. It should be mention that the soil organic $C$ content was greater in the surface layer $(0-15 \mathrm{~cm})$ than the sub-surface layer (15-30, 30-45 and $45-60 \mathrm{~cm}$ ) for all treatments. The higher content of SOC content in the surface soil is mainly due to organic manure incorporated in the surface layer. Overall, the higher organic carbon content $\left(31.5 \mathrm{~g} \mathrm{~kg}^{-1}\right)$ was pronounced after long-term of organic manure application (15-years) in soil samples under fruit trees. These results indicate that long-term additions of organic manure would have the beneficial effects in building carbon pools in soils of arid conditions. An increase in contents of soil organic carbon in soil amended with manure has been reported by several researchers (Gong et al., 2008; Manna et al., 2005). The increase in nutritional status of soils due to the continuous addition of organic manure can result in an increase of plant residues, which could be accumulated in the surface soil and subsequently it results in higher content of soil organic carbon.

\section{Effects of organic manure on soil available $\mathbf{N}$ and $\mathbf{P}$}

Figures 2 and 3 show the average values of the amount of available $\mathrm{N}$ and $P$ in soils as affected by organic manure application. In addition, Table 2 shows significance at the 0.05 and 0.01 probability levels. Data show that the soil available $\mathrm{N}$ ranged between 30 and $67 \mathrm{mg} \mathrm{kg}^{-1}$ after organic manure application for the first year and between 35 and $211 \mathrm{mg} \mathrm{kg}^{-1}$ after manure application for the 15 year in soil samples cropped with fruit trees (Figure 2). Moreover, the soil available $\mathrm{N}$ ranged between 22 and 62, 50 and 140, and 50 and $162 \mathrm{mg} \mathrm{kg}^{-1}$ after organic manure application for the five month, the first year and the second year in soil samples cropped with vegetable plants. It should be mentioned that the soil available $\mathrm{N}$ was greater in the surface layers $(0-15 \mathrm{~cm}$ and $15-30 \mathrm{~cm})$ than the sub-surface layers $(30-45$ and $45-60 \mathrm{~cm})$ layers, which is attributed mainly to organic manure incorporated in the surface layer. Overall, our results showed that the higher soil available $\mathrm{N}\left(211 \mathrm{mg} \mathrm{kg}^{-1}\right)$ was pronounced after long term of organic manure application (15-years) in soil samples cropped with fruit trees followed by that found after the two-years organic manure application to the soil of vegetable plants. An increase in the availability of $\mathrm{N}$ in soil amended with manure has been reported by several researchers (Gong et al., 2008; Hou et al., 2012; Eghball, 2000; Zaman et al., 2004). It has been reported that continuous application of compost and noncomposted manure increased $\mathrm{N}$ mineralization (Eghball, 2000), reflecting on

Vol. 20(3), 2015 
enhancing plant growth. Zaman et al. (2004) reported also that the long-term application of organic amendments resulted in a positive impacts on $\mathrm{N}$ mineralization, mainly due to enhancing microbial and enzyme activities.
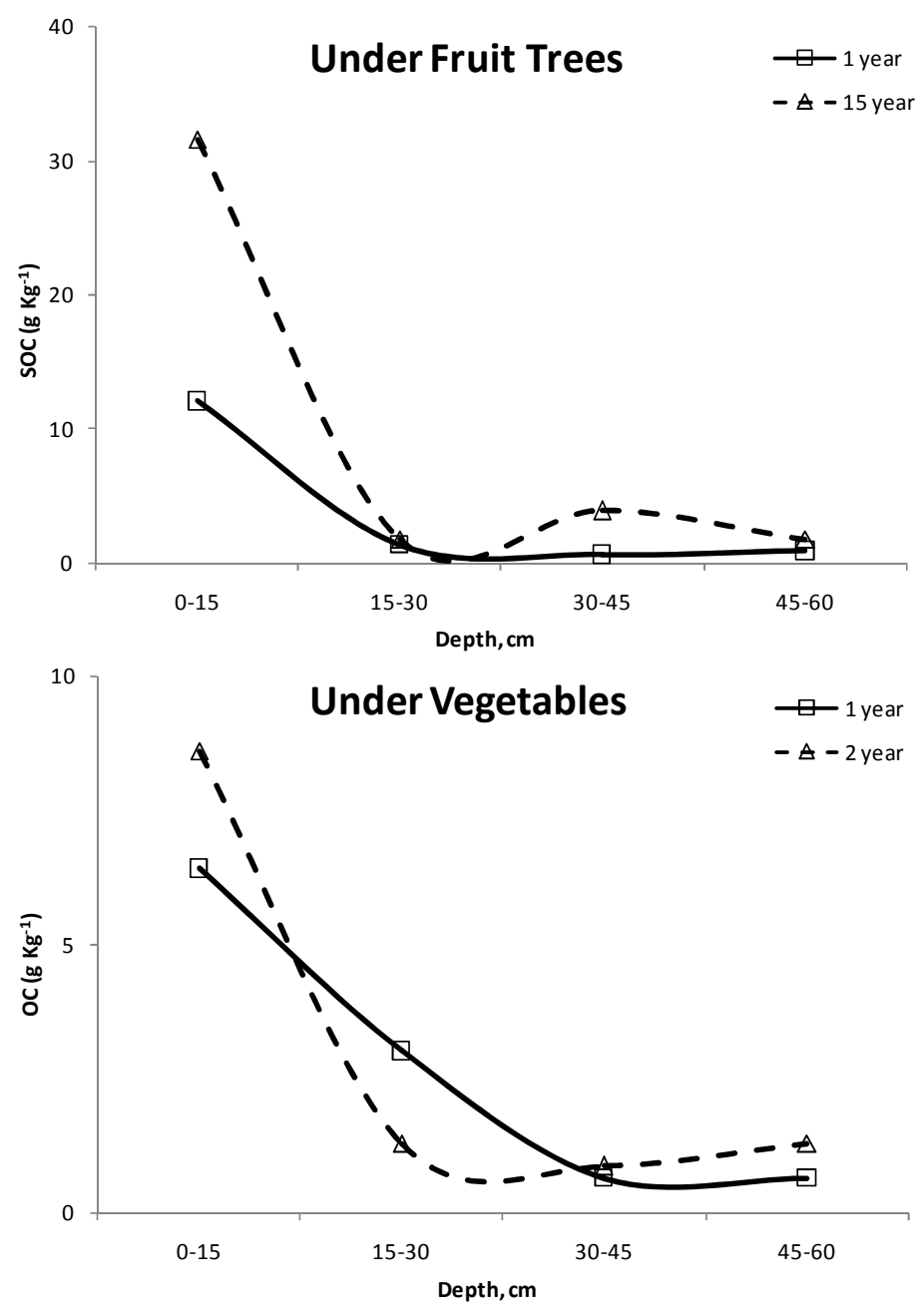

Fig. (1). Distribution of soil organic carbon (SOC) in soil profile under fruit trees and vegetable crops

Soil available $P$ ranged between 0.5 and $2.8 \mathrm{mg} \mathrm{kg}^{-1}$ after organic manure application for the 1-year and between 0.9 and $52 \mathrm{mg} \mathrm{kg}^{-1}$ after manure application for the 15-years in soil samples cropped with fruit trees (Figure 3). Moreover, the soil available $P$ ranged between 1.5 and 9.2 , and 0.2 and 60.2 $\mathrm{mg} \mathrm{kg}^{-1}$ after organic manure application for the 1-year and the 2-years in soil samples cropped with vegetable plants. Similar to $N$, the soil available $P$ was greater in the surface layers $(0-15 \mathrm{~cm})$ than the sub-surface layers $(15-30 \mathrm{~cm}$, $30-45 \mathrm{~cm}$ and $45-60 \mathrm{~cm}$ ), which is mainly due to organic manure incorporated in the surface layer. Overall, our results showed that the higher soil available $P$ (52-60.2 mg kg-1) was reported after 15-years and 2-years application of organic manure in soil samples cropped with fruit trees and vegetable plants.

In soil samples of fruit trees, there is significant relationship between soil organic $C$ content and soil available $N\left(r^{2}=0.57\right)$ or soil available $P\left(r^{2}=0.88\right)$ (Figure 4). Moreover, in soil samples cropped with vegetable plants, there is 
significant relationship between soil organic $C$ content and soil available $P\left(r^{2}=\right.$ 0.71) (Figure 5). The general factors controlling $P$ solubility and availability in the soil include soil $\mathrm{pH}, \mathrm{Fe}$ and $\mathrm{Al}$ oxides, organic matter, and the presence of other elements such as N, S, and cations. The application of organic materials to calcareous soils can decrease $P$ adsorption, possibly due to competition between $P$ ions and organic anions or retention sites in the soil (Hue, 1991; lyamuremye et al., 1996a; 1996b; 1996c). Decomposition of organic matter by soil microorganisms also produces $\mathrm{CO}_{2}$ which dissolves in water to form carbonic acid, increasing the solubility of $\mathrm{Ca}-\mathrm{P}$ and $\mathrm{Mg}-\mathrm{P}$ precipitates in alkaline soils.

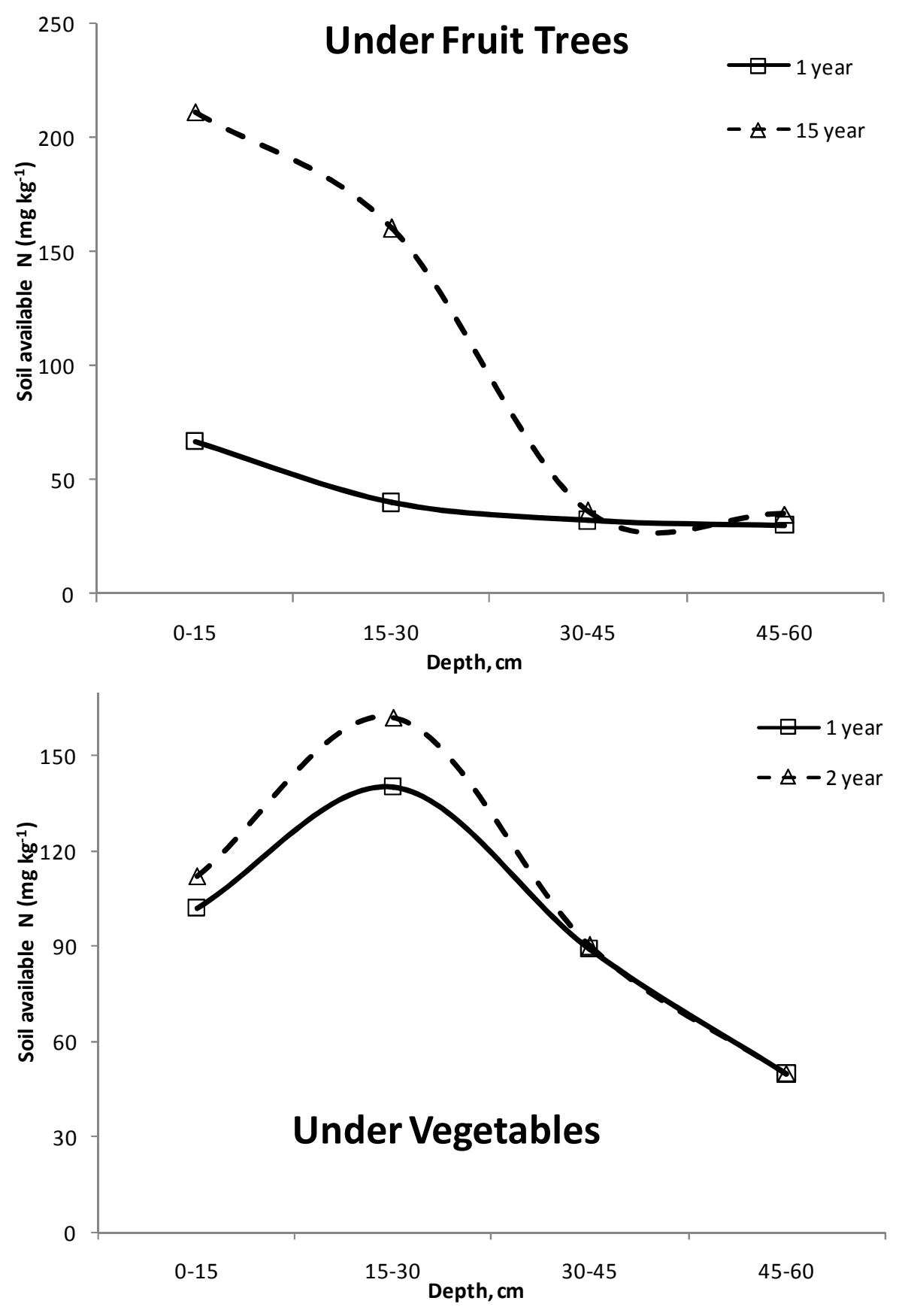


Fig.(2). Distribution of soil available $N$ in soil profile under fruit trees and vegetable crops
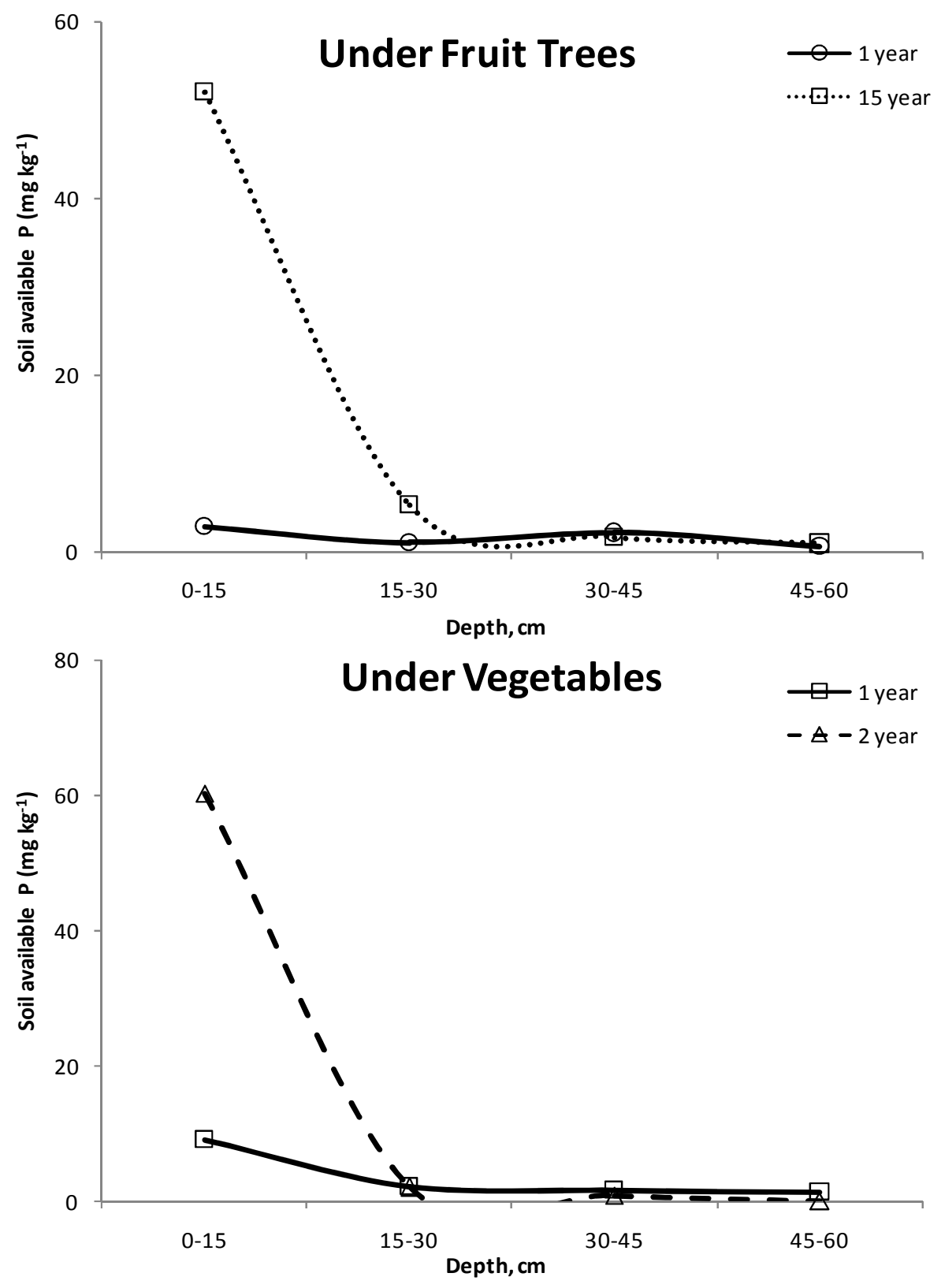

Fig. (3). Distribution of soil available $P$ in soil profile under fruit trees and vegetable crops. 

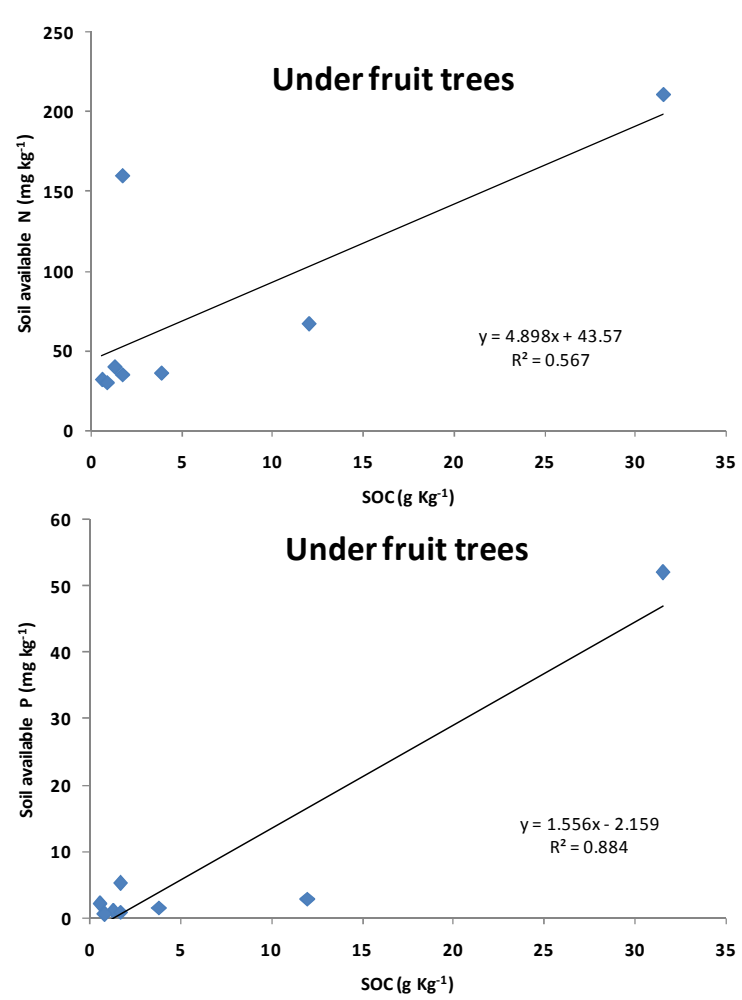

Fig.(4). Relationship between soil organic carbon (SOC) and soil available $\mathbf{N}$ and $\mathbf{P}$ in soil samples of fruit trees.
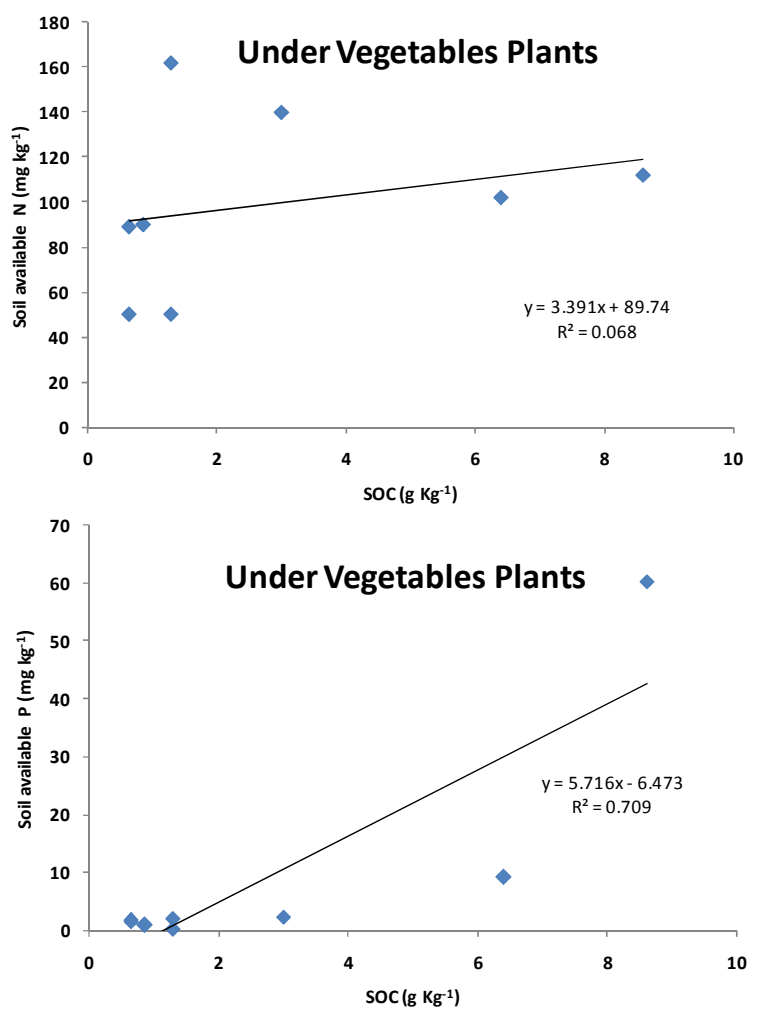

Fig. (5). Relationship between soil organic carbon (SOC) and soil available $\mathbf{N}$ and $\mathbf{P}$ in soil samples of vegetable crops. 


\section{CONCLUSIONS}

The long-term application of organic manure resulted in greater $\mathrm{C}$ sequestration in agricultural soils. In this study, the accumulation of SOC was greater in the surface layer of the soil as compared to subsurface layers. In addition, SOC accumulation, applying organic manure to the soils improved soil fertility by increasing the availability of $\mathrm{N}$ and $\mathrm{P}$. However, future study should focus on $\mathrm{C}$ fractions that are more sensitive for the changes in SOC. In addition, the effect of the agriculture practices on soil $C$ sequestration should be investigated under arid conditions.

\section{REFERENCES}

Bouajil, K. and M. Sana (2011). Effects of organic amendments on soil physico-chemical and biological properties. J. Mater. Environ. Sci., 2 (S1) : 485-490.

Diacono, M. and F. Montemurro (2010). Long-term effects of organic amendments on soil fertility. A review. Agron. Sustain. Dev., 30 : 401422.

Eghball, B. (2000). Nitrogen mineralization from field-applied beef cattle feedlot manure or compost, Soil Sci. Soc. Am. J., 64: 2024-2030.

Gee, G. W. and J. W. Bauder (1994). Particle-size Analysis. 377-382. In Methods of Soil Analysis. Part 1, $3^{\text {rd }}$ edition. Physical and Mineralogical Methods. Edited by Klute, A. SSSA and ASA, Madison, WI.

Gong, W., X. Y. Yan, Z. C. Cai, J. Y. Wang, T. X. Hu, Y. B. Gong and H. Ran (2008). Effects of long-term fertilization on soil particulate organic carbon and nitrogen in a wheat-maize cropping system. The Journal of Applied Ecology, 19(11): 2375-81.

Hou, X., X. Wang, R. Li, Z. Jia, L. Liang,J. Wang, J. Nie, X. Chen and Z. Wang (2012). Effects of different manure application rates on soil properties, nutrient use, and crop yield during dryland maize farming. Soil Research, 50(6): 507-514.

Hue, N.V. (1991). Effects of organic acids/anions on $P$ sorption and phytoavailability in soils with different mineralogies. Soil Sci., 152: 463471.

lyamuremye, F., R. P. Dick and J. Baham(1996a). Organic amendments and phosphorus dynamics: II. Distribution of soil phosphorous fractions. Soil Sci., 161: 436-443.

lyamuremye, F., R. P. Dick and J. Baham (1996b). Organic amendments and phosphorous dynamics: III: Phosphorous speciation. Soil Sci., 161: 44451.

lyamuremye, F., R. P. Dick and J. Baham (1996c). Organic amendments and phosphorous dynamics: I. Phosphorous chemistry and sorption. Soil Sci., 161: 426-435.

Johansson, M., B. Stenberg, and L. Torstensson (1999). Microbiological and chemical changes in two arable soils after long-term sludge amendments. Biol. Fertil. Soils, 30: 160-167.

Keeney, D.R. and D. W. Nelson (1982). Nitrogen in organic forms. In A. L. Page, R.H. Miller, and D.R. Keeney, Eds. Methods of Soil Analysis. Part 2. Agronomy No. 9, American Society of Agronomy, Madison, WI, pp. 643-698.Magill, A.H. and Aber, J.D. 2000. 
Manna, M.C., A. Swarup , R.H. Wanjari, H.N. Ravankar, B. Mishra, M.N. Saha, Y.V. Singh, D. K. Sahi and P. A. Sarap (2005). Long-term effect of fertilizer and manure application on soil organic carbon storage, soil quality and yield sustainability under sub-humid and semi-arid tropical India. Field Crops Research, 93: 264-280.

Miller, D.M., W. P. Miller(2000). Land application of wastes, in: Sumner M. (Ed.), Handbook of soil science, CRC Press, Chap. 9.

Morera, M.T., J. Echeverria, and J. Garrido(2002). Bioavailability of heavy metals in soils amended with sewage sludge. Can. J. Soil Sci., 82: 433438.

Nelson, D.W. and L. E. Sommers (2005). Total carbon, organic carbon, and organic matter. In. Methods of soil analysis. Part 3. Chemical Methods. Edited by Sparks et. al., SSSA and ASA, Madison, WI. , 961-1010.

Olsen, S. R. and L. E. Sommers (1982). Phosphorus. p403-430. In: A.L. Pageetal(eds.), Methods of soil analysis, part2. Agron. Mong. 9. $2^{\text {nd }}$ ed. ASA and SSSA, Madison, WI.

Richards, J.E., T.E. Bates and S.C. Sheppard (1995). Changes in the forms and distribution of soil $\mathrm{P}$ due to long-term corn production. Can J. Soil. Sci., 75: 311-318.

Soil Survey Staff (2006). Keys to Soil Taxonomy, $10^{\text {th }}$ edition. U.S. Department of Agriculture, Natural Resources Conservation Service. Washington, DC.

Soltanpour, P.N., and S. Workman (1979). Modification of the NH4HCOrDTPA soil test to omit carbon black. Commun. Soil Sci. Plant Anal., 10:1411-1420

Sparks, D. L.(1996). Methods of Soil Analysis, Madison, Wi : Soil Society of American.

StatSoft, Inc.(1995). Statistica for Windows (Computer Program Manual). StatSoft,Inc., Tulsa, OK,

Tejada, M., J. L. Gonzalez, A. M. García-Martínez and J. Parrado (2008). Application of a green manure and green manure composted with beet vinasse on soil restoration: Effects on soil properties, Bioresource Technol., 99: 4949-4957.

Triberti, L., A.Nastri, G. Giordani, F. Comellini, G. Baldoni and G. Toderi (2008). Can mineral and organic fertilization help sequestrate carbon dioxide in cropland? European Journal of Agronomy, 29: 13-20

Wassif, M. M., M. M. K. Shababa, S. M. Sead,S. E. El-Maghraby, and I. A. Ashour(1995). Influence of some soil amendments on calcareous soil properties and its productivity of wheat under highly saline irrigation water. Egypt. J. Soil Sci., 35: 439-451.

Zaman, M., M. Matsushima, S. X. Chang, K. Inubushi, L. Nguyen, S. Goto, F. Kaneko and T. Yoneyama (2004). Nitrogen mineralization, $\mathrm{N}_{2} \mathrm{O}$ production and soil microbiological properties as affected by longterm applications of sewage sludge composts, Biol. Fert. Soils, 40: 101-109. 


\section{الملخص العربي \\ تأثير الإضافات المستمرة للأسمدة العضوية على الخصائص الكيميائية والكريون \\ العضوي فى الأراضى المزروعة}

\section{عبد الرحمن سعد المالك}

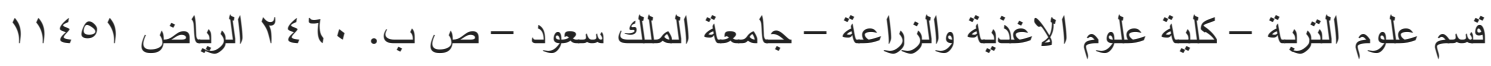
المملكة العربية السعودية

أجريت هذه الدراسة لتقدير الآثار المترتبة على إضافة الأسمدة العضوية على فترات قصيرة وطويلة الأجل على خواص التربة الكيميائية والتي شملت حموضة التربة، والملوحة، كربونات الكالسيوم، الكربون العضوي، والعناصر الميسرة (النيتروجين والفوسفور) تحت الظروف الجافة. تم تطبيق إضافة السماد العضوي الصلب إلى التربة لفترة تصل إلى عامين فى الأراضي المزروعة بمحاصيل الخضر ، 10 عاماً فى الأراضى المنزرعة بأشجار الفاكهة. تم

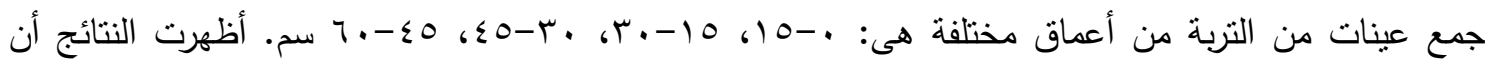

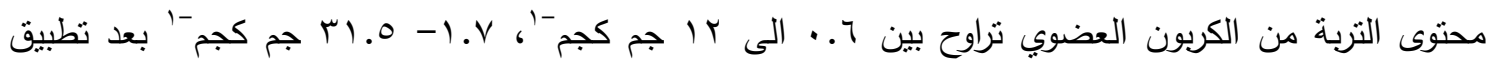

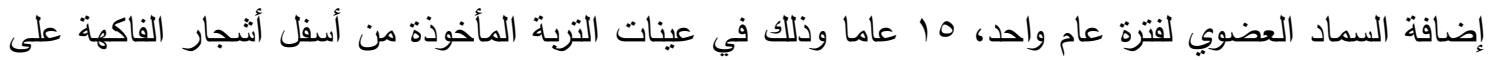

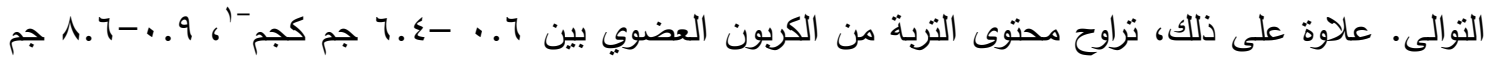

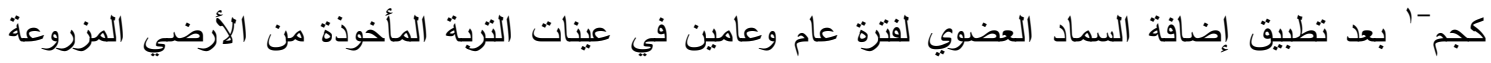

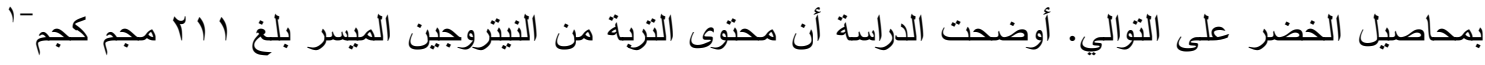

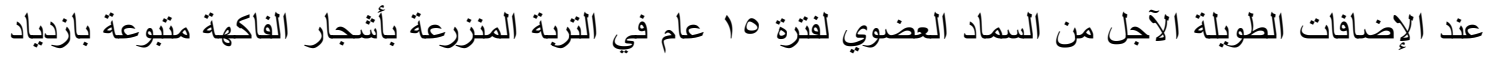
بلغ بآ1 مجم كجم -' عند الإضافات الطويلة الآجل (عامين) من السماد العضوي في التربة المنزرعة بمحاصيل الخضر. عموما، إن إضافة السماد العضوي للتربة تحت الظروف الجافة قد يكون مناسباً للحفاظ على محتوى لإنى التربة من الكربون العضوي وتحسين خصوبتها من خلال زيادة نوافر العناصر الغذائية بها كالنيتروجين والفوسفور . الكلمات الافتتاحيه : السماد العضويه ، الكربون العضوى ، النيتروجين الميسر ، الفوسفور الميسر . 
